\title{
Correction to: Financialisation: continuity and change-introduction to the special issue
}

\section{Engelbert Stockhammer ${ }^{1} \cdot$ Stefano Sgambati $^{2} \cdot$ Anastasia Nesvetailova $^{3}$}

Published online: 14 December 2021

(c) European Association for Evolutionary Political Economy 2021

\section{Correction to: Review of Evolutionary Political Economy https://doi.org/10.1007/s43253-021-00061-4}

The editorial referenced the paper of Davis and McCormack (2021) incorrectly as Davis (2021). The correct reference is:

Davis L, McCormack J (2021) Industrial stagnation and the financialization of nonfinancial corporations. Review of Evolutionary Political Economy 2, 3.

The correct affiliation of Anastasia Nesvetailova is UNCTAD, Geneva.

The original article has been corrected.

The online version of the original article can be found at https://doi.org/10.1007/s43253-021-00061-4

Engelbert Stockhammer

engelbert.stockhammer@kcl.ac.uk

$1 \quad$ King's College London, London, UK

2 City, University of London, London, UK

3 UNCTAD, Geneva, Switzerland 